\title{
Pengaruh Model Pembelajaran Think Talk Write (TTW) Terhadap Peningkatan Kemampuan Menulis matematis Siswa SMA Ditinjau Dari Self Efficacy
}

\author{
(The Effect of Think Talk Write (TTW) Learning Model on Increased Mathematical Writing \\ Ability of High School Students In Termss Of Self Efficacy) \\ Hardianti $^{1}$, Kodirun ${ }^{2}$, Lambertus ${ }^{2}$ \\ ${ }^{1}$ Alumnus Prodi Pendidikan Matematika PPs Universitas Halu Oleo \\ ${ }^{2}$ Dosen Pendidikan Matematika FKIP dan PPS Universitas Halu Oleo; Co-author: \\ kodirun_zuhry@yahoo.co.id
}

\begin{abstract}
Abstrak: Penelitian ini bertujuan untuk; mengetahui perbedaan rata-rata peningkatan kemampuan menulis matematis siswa yang diajar dengan model pembelajaran TTW dan siswa yang diajar dengan model pembelajaran konvensional; mengetahui perbedaan pengaruh antara penerapan model pembelajaran TTW dan penerapan model pembelajaran konvensional terhadap kemampuan menulis matematis siswa ditinjau dari Self efficacy. Penelitian ini dilakukan pada siswa kelas X MIA SMA Negeri 3 Kendari.Pengambilan sampel dalam penelitian ini menggunakan teknik purposive sampling dan random sampling.Data dianalisis dengan statistik inferensial dengan two way anova dan uji beda dua rata-rata. Hasil penelitian menunjukkan bahwa: Secara signifikan ratarata peningkatan kemampuan menulis matematis siswa yang diajar dengan model pembelajaran TTW lebih tinggi dibandingkan dengan rata-rata penningkatan kemampuan menulis matematis siswa yang diajar dengan model pembelajaran konvensional; terdapat perbedaan pengaruh yang signifikan antara penerapan model pembelajaran TTW dan penerapan model pembelajaran konvensional terhadap kemampuan menulis matematis siswa ditinjau dari self efficacy.
\end{abstract}

Kata kunci: Kemampuan Menulis Matematis, Self Efficacy, TTW

\begin{abstract}
This study aimed to: find out the difference in the averages of increase in mathematics writing ability of students who were taught via TTW learning model and their cohorts who were nstructed in a conventional learning model learning model; find out the difference in the effect of applying TTW lerning model and the conventional learning model on the increase in students mathematics writing ability viewed from their self- efficacy. The study included students of class $\mathrm{X}$ MIA at SMA Negeri 3 of Kendari. Samples of the study were drawn using a purposive random sampling technique. Data were analyzed using a descriptive statistics and inferential statistics using two way anova and two different means test. Results of the study showed that; the average of increase in the mathematics writing ability gained by the students who were taught under the TTW learning model was significantly higher than that achieved by those instructed in the conventional model; There was a significant difference between the effect of TTW learning model and that of the conventional model on the improvement of students' mathematics writing ability as viewed from self- efficacy.
\end{abstract}

Keywords: Mathematics Writing Ability, Self-Efficacy, TTW

\section{PENDAHULUAN}

Perkembangan dunia pendidikan menuntut guru untuk efektif dalam berkomunikasi dengan siswa.Rendahnya komunikasi antara guru dengan siswa dapat menyebabkan siswa merasa bosan dan kurang tertarik mengikuti pelajaran sehingga hasil yang diharapkan dari komunikasi pembelajaran tidak sesuai harapan. Kemampuan komunikasi mempunyai peranan yang penting dalam

kegiatan belajar. Menurut Effendy (2000: 13), komunikasi adalah proses penyampaian pikiran atau perasaan oleh seseorang kepada orang lain dengan menggunakan lambang-lambang yang bermakna bagi kedua pihak, dalam situasi yang tertentu komunikasi menggunakan media tertentu untuk merubah sikap atau tingkah laku seorang atau sejumlah orang 
sehingga ada efek tertentu yang diharapkan.

National Council of Teachers of Mathematics (NCTM) telah menetapkan lima tujuan umum pembelajaran matematika yaitu komunikasi matematika, bernalar matematika, memecahklan masalah matematika, koneksi matematika, pembentukan sikap positif terhadap matematika (Van de Walle, 2008). Komunikasi merupakan kemampuan yang perlu dimiliki dan dikembangkan oleh siswa. Melalui komunikasi matematis siswa dapat mengorganisasi dan mengkonsolidasi berpikir matematisnya baik secara lisan maupun tulisan.Matematika pada dasarnya adalah bahasa yang sarat dengan notasi dan istilah. Jika mempunyai kemampuan komunikasi maka konsep yang terbentuk dapat dipahami oleh siswa. Selain itu, siswa juga dapat memberikan respon yang tepat antar siswa dan media dalam proses pembelajaran. Dalam pergaulan bermasyarakat seseorang yang mempunyai kemampuan komunikasi yang baik akan lebih mudah beradaptasi dengan siapa pun.

Ide-ide matematik peserta didik dapat dipahami orang lain jika ide tersebut dapat di $\neg$ komunikasikan dengan baik. Salah satu cara mengungkapkan ide matematika adalah melalui bahasa tulis, karena menulis merupakan sarana yang sangat penting (powerfull) untuk membangun jaringan mental anak (Junaedi, 2005). Suatu ide-ide atau konsep matematika akan mudah dipahami jika konsep yang baru terkait dengan konsep atau pengetahuan yang lama yang dimiliki anak. Menurut Junaedi (2005), beberapa keuntungan dari menulis matematika antara lain: (a) dapat meningkatkan pemahaman, (b) meningkatkan penalaran dan problem solving, (c) dapat sebagai stimulasi untuk problem posing, dan (d) membuat mandiri dan independent dalam belajar. Salah satu kegiatan menulis matematika adalah membuat rangkuman pembelajaran matematika. Kegiatan membuat rangkuman akan melibatkan kemampuan berpikir matematika, pemahaman matematika dan proses matematika (doing math).

Dari studi pendahuluan yang dilakukan di SMA Negeri 3 Kendari tahun 2016 kelas X MIA 2, dengan jumlah siswa 22 orang untuk mengukur tingkat kemampuan menulis matematis siswa dengan indikator yang diteliti yaitu written text dan mathematical exspression. Hasil yang diperoleh nilai rata-rata kemampuan menulis matematis siswa adalah 36 . Ini artinya bahwa kemampuan menulis matematis siswa belum mencapai kategori yang baik, terutama pada indikator written texts. Sebagian besar siswa belum dapat menuliskan kalimat matematika dengan baik, banyak simbol yang salah, masih kurang paham menuliskan apa yang diketahui , ditanyakan dan penyelesaian masalah dalam model matematika, serta masih terdapat kesalahan prosedur penyelesaian masalah.

Selain dari fakta di atas, berdasarkan hasil wawancara guru matematika kelas $\mathrm{X}$ MIA di SMA Negeri 3 Kendari, dalam proses pembelajaran aspek menulis matematis tidak ditekankan, baik dalam mencatat maupun mengerjakan soal. Siswa tidak terbiasa mengerjakan soal esai yang dapat memaksa mereka untuk menuliskan ide-ide yang muncul dalam pikiran mereka, sehingga mereka tidak terbiasa mengeksplorasi ide-ide dan mengasah kemampuan menulis matematisnya.Dalam penyelesaian soal, sering ditemukan siswa menuliskan symbol atau bahasa matematika yang kurang tepat. Padahal guru, tersebut mengakui bahwa penulisan yang salah akan menimbulkan persepsi yang salah sehingga pemahaman konsep siswapun menjadi rendah. Akan tetapi, aspek tersebut diabaikan begitu saja.

Hal yang terlihat sepele ini dapat menimbulkan masalah serius jika dibiarkan. Pasalnya, menulis matematis merupakan sarana penanaman sekaligus sebagai refleksi dari pemahaman konsep 
seseorang dikarenakan tulisan adalah salah satu bentuk representasi bahasa yang digunakan dalam penyampaian suatu informasi. Jika terdapat penulisan yang salah maka akan menimbulkan pembaca dalam menerima informasi yang seharusnya. Masalah lain yaitu masih banyak siswa yang mengalami kesulitan dalam melakukan operasi matematika khususnya bilangan pecahan, masih banyak siswa yang mengalami kesulitan dalam memahami soal cerita dan banyak siswa yang mengalami kesulitan dalam mengerjakan soal yang sedikit berbeda dengan contoh yang sudah diberikan.

Masih banyak guru yang menggunakan model pembelajaran konvensional yang menyebabkan siswa kurang memiliki kesempatan untuk mengungkapkan ide-ide matematika, memberi penjelasan atas jawabnnya, atau menanggapi pendapat orang lain. Hal ini menyebabkan siswa tidak dapat mengembangkan kemampuan matematisnya. Oleh karena itu, dalam pembelajaran matematika hendaknya guru selalu mendorong kemampuan siswa dalam komunikasi. Memberikan kesempatan kepada siswa untuk mengembangkan keterampilan komunikasi dalam matematika menjadi sebuah sifat dasar dari pengembangan program matematika yang baik, sebagai hasilnya siswa akan senang mengekspresikan hasil pemikirannya.

Selain kemampuan komunikasi, ada aspek psikologis yang memberikan kontribusi terhadap keberhasilan seseorang dalam menyelesaikan tugas dengan baik.Aspek psikologis tersebut adalah self-efficacy. Wilson dan Jones (2008) menyatakan bahwa self-efficacy merupakan salah satu faktor penting dalam menentukan prestasi matematika seseorang. Banyak peneliti yang melaporkan bahwa self-efficacy siswa berkorelasi dengan kontruksi motivasi, kinerja dan prestasi siswa.
Teori sosial kognitif Bandura (1997; 3), dikenal istilah self-efficacy yang mempengaruhi pilihan aktivitas, usaha seseorang dalam menyelesaikan tugastugas yang dihadapi.Dalam kegiatan belajar, self-efficacy membuat siswa memilih mengerjakan atau menghindari suatu aktivitas belajar. Bandura mendefinisikan self efficacy sebagai judgement seseorang atas kemampuannya untuk merencanakan dan melaksanakan tindakan yang mengarah pada pencapaian suatu tujuan/hasil tertentu.

Berdasarkan latar belakang yang telah diuraikan di atas, maka untuk meningkatkan kemampuan siswa dalam menulis matematis dalam penelitian ini akan diaplikasikan pembelajaran kooperatif tipe Think Talk Write (TTW). Pembelajaran TTW merupakan pembelajaran yang diduga penting untuk dapat meningkatkan kemampuan siswa dalam menulis matematis.

Strategi TTW dikenalkan oleh Huinker dan Laughlin $(1996 ; 82)$ ini pada dasarnya dibangun melalui berfikir, berbicara dan menulis. Strategi ini diawali dengan peserta didik membaca materi yang sudah dikemas dengan pendekatan konstruktivis untuk memahami kontennya (think), kemudian peserta didik mengkomunikasikan untuk mendapatkan kesamaan pemahaman (talk), dan akhirnya diskusi serta negosiasi, peserta didik menuliskan hasil pemikirannya dalam bentuk rangkuman (write). Pembelajaran kooperatif tipe TTW dipilih dengan maksud untuk dapat memberi tempat kepada siswa yang dibentuk dalam kelompok-kelompok kecil yang beragam kemampuannya yang bekerja sama dalam suatu pembelajaran. Pembelajaran seperti ini diharapkan dapat meningkatkan kemampuan siswa dalam menulis matematis.

Berdasarkan keadaan tersebut peneliti menyampaikan gagasan untuk melaksanakan suatu penelitian dengan judul "Pengaruh Model Pembelajaran 
Think Talk Write (TTW) terhadap Peningkatan Kemampuan Menulis Matematis Siswa SMA ditinjau dari SelfEfficacy."

Tujuan penelitian ini adalah untuk mengkaji dan menganalisis; 1) Deskripsi kemampuan menulis matematis siswa yang diajar dengan model pembelajaran Think Talk Write (TTW) dan siswa yang diajar dengan model pembelajaran konvensional; 2) Deskripsi kemampuan menulis matematis siswa yang memiliki

\section{METODE PENELITIAN}

Jenis Penelitian ini adalah penelitian eksperimen semu (quasi experimental), pada pelaksanaannya peneliti menggunakan kelas eksperimen dan kelas kontrol serta peneliti tidak mungkin mengontrol semua variabel yang relevan. Pada kelompok eksperimen, peneliti memberi perlakuan pembelajaran dengan menggunakan pembelajaran Think Talk Write (TTW), yang bertujuan untuk melihat gejala atau dampak yang ditimbulkan pada diri siswa terkait dengan kemampuan menulis matematisditinjau dari self efficacy. Selanjutnya, pada kelompok kontrol, peneliti menggunakan pembelajaran konvensional, yang bertujuan untuk melihat gejala atau dampak yang ditimbulkan pada diri siswa terkait dengan kemampuan menulis matematisditinjau dari self efficacy. Hal ini dilakukan untuk melihat apakah ada perbedaan, atau membandingkan nilai rata-rata kemampuan menulis matematisditinjau dari self efficacy pada kelompok eksperimen dengan kelompok kontrol.

Rancangan desain yang digunakan dalam penelitian ini adalah PretestPosttest Control Group Design yang disajikan sebagai berikut:

$\begin{array}{llll}\mathrm{KE} & \mathrm{O}_{1} & \mathrm{X}_{1} & \mathrm{O}_{2} \\ \mathrm{KK} & \mathrm{O}_{1} & & \mathrm{O}_{2}\end{array}$

(Sugiyono, 2011)

Penelitian ini dilaksanakan pada siswa kelas $\mathrm{X}$ MIA di SMA Negeri 3 self efficacy tinggi, sedang dan rendah; 3) Perbedaan rata-rata peningkatan kemampuan menulis matematis siswa yang diajar dengan model pembelajaran TTW dan siswa yang diajar dengan model pembelajaran konvensional; 4) Perbedaan pengaruh penerapan model pembelajaran TTW dan penerapan model pembelajaran konvensional terhadap kemampuan menulis matematis siswa ditinjau dari Self efficacy.

Kendari, Kota Kendari, Provinsi Sulawesi Tenggara.Penelitian ini dilaksanakan pada semester genap tahun pelajaran 2016/2017 sesuai dengan jadwal pelajaran yang ada di sekolah.

Subjek populasi dalam penelitian ini adalah siswa kelas X MIA di SMA Negeri 3 Kendari, Kota Kendari, Provinsi Sulawesi Tenggara.Metode penarikan sampel yang digunakan adalah purposive sampling dan Random Sampling. Subjek sampling diperoleh dengan cara purposive sampling yaitu teknik pengambilan sampel berdasarkan pertimbangan tertentu (Sugiyono, 2011). Cara yang dilakukan adalah dengan memilih siswa kelas $\mathrm{X}$ MIA atas dasar pertimbangan: Siswa kelas $\mathrm{X}$ MIA terdiri atas limakelas dengan kemampuan siswanya yang tersebar secara heterogen.Artinya di dalam suatu kelas terdapat siswa yang berkemampuan tinggi, sedang dan rendah.Kemudian untuk memilih dua kelas, kelas eksperimen dan kelas control dilakukan secara acak melalui undian. Kelas yang diundi adalah kelas yang memiliki kemampuan matematika dan varians yang relatif sama. Hasil Random kelas diperoleh kelas X. MIA 3 sebagai kelas eksperimen dan X.MIA 1 sebagai kelas control.

Terdapat tiga variabel dalam penelitian eksperimen ini yaitu sebagai berikut:1) Variabel bebas yang berupa perlakuan yakni penerapan pembelajaran TTW (X); 2) Variabel terikat yang berupa 
kemampuan menulis matematis(Y); 3) Variabel moderat dalam penelitian ini adalah self efficacy siswa dengan kategori tinggi, sedang, dan rendah.

Jenis data dalam penelitian ini merupakan data kuantitatif yang diperoleh dari hasil tes kemampuan menulis matematis danself efficacy serta data kualitatif yang diperoleh dari lembar observasi. Data dalam penelitian ini diperoleh langsung oleh peneliti.Teknik pengumpulan data yang digunakan pada penelitian ini adalah teknik tes dan teknik angket.Teknik tes digunakan untuk mengumpulkan data yang berkaitan dengan kemampuan menulis matematis siswa. Sedangkan teknik angket digunakan untuk mengumpulkan data yang berkaitan dengan self efficacy siswa sebelum perlakuan dengan tujuan membagi siswa ke dalam 3 kelompok yaitu siswa yang mempunyai self efficacy tinggi, self efficacy sedang, dan self efficacy rendah.

Dalam penelitian ini, instrumen yang digunakan untuk mengumpulkan data adalah instrumen tes dan instrumen non tes. Instrumen tes berupa tes kemampuan menulis matematis dan instrumen non tes berupa angket skala self efficacy dan lembar observasi siswa dan guru yang berkaitan dengan pembelajaran TTW. Tes kemampuan kemampuan menulis matematis ini berupa tes uraian yang diberikan pada saat pre test sebelum proses pembelajaran selesai dan post testsetelah proses pembelajaran selesai. Pretest dan posttest diberikan pada kelas eksperimen dan kelas kontrol. Pretest diberikan pada awal kegiatan penelitiandan posttest diberikan pada akhir kegiatan penelitian. Hasil pretestdan posttest ini digunakan untuk melihat

\section{HASIL PENELITIAN}

Data kemampuan menulis matematis siswa diperoleh melalui tes kemampuan menulis matematis. Tes kemampuan menulis matematis diberikan kepada kelompok eksperimen yang diajar peningkatan kemampuan menulis matematis siswa baik di kelas eksperimen maupun di kelas kontrol.

Analisis data dilakukan secara kuantitatif.Sebelum data dianalisis, terlebih dahulu dihitung peningkatan kemampuan komunikasi matematik dengan $N$ Gain.Untuk memperoleh kesimpulan tentang pengaruh pembelajaran TTW pada kelas eksperimen dan pembelajaran konvensional pada kelas control terhadap kemampuan menulis matematis siswa berdasarkan self efficacy dilakukan analisis deskrptif dan analisis inferensial.

Analisis deskriptif dilakukan terhadap hasil tes kemampuan menulis matematis sebelum dan setelah mendapat pembelajaran TTW pada kelas eksperimen dan pembelajaran konvensional pada kelas kontrol. Analisis deskriptif pada penelitian ini diperlukan untuk mendeskripsikan karakteristik variabel terikat dalam hal ini hasil tes kemampuan menulis matematis siswa melalui rata-rata (mean), median, modus, standar deviasi, varians, minimum, maksimum, dan range. Selain itu dilakukan analisis deskripsi kualitatif hasil observasi guru dan siswa pada pembelajaran dengan menggunakan pembelajaran TTW dan pembelajaran konvensional. Analisis deskriptif pada penelitian ini akan menggunakan bantuan perangkat lunak SPSS.

Analisis inferensial dimaksudkan untuk menguji hipotesis pengaruh pembelajaran TTW pada kelas eksperimen dan pembelajaran konvensional pada kelas kontrol. terhadap kemampuan menulis matematis siswa berdasarkan Self efficacy.

dengan TTW maupun kelompok kontrol yang diajar dengan konvensional, masing masing dilakukan dua kali yaitu sebelum pemberian perlakuan (pretest) dan setelah perlakuan (post test). 
Deskripsi data pre test, post test dan N- Gain kemampuan menulisa matematis siswa untuk kelas eksperimen dan kontrol disajikan dalam tabel berikut:

Tabel 1. Deskripsi Kemampuan Menulis Matematis Siswa Kelas Eksperimen dan Kontrol

\begin{tabular}{ccccccc}
\hline Deskriptif & $\begin{array}{c}\text { Pre } \\
\text { test }\end{array}$ & Post test & N-gain & Pre test & Post test & N-gain \\
\hline Rata-rata & 50,75 & 73,66 & 0,47 & 49,45 & 63,22 & 0,28 \\
Simpangan & 14,12 & 13,64 & 0,20 & 14,34 & 16,16 & 0,21 \\
Baku & & 45,83 & 0,00 & 31,25 & 37,50 & 0,00 \\
Minimum & 25,00 & 41,67 & 0,73 & 81,25 & 91,67 & 0,71 \\
Maksimum & 75,00 & 91,67 & & & & \\
\hline
\end{tabular}

Berdasarkan Tabel 1, diperoleh bahwa pada kelas eksperimen atau kelas yang diajar dengan TTW nilai rata-rata pre test sebesar 50,75 dengan simpangan baku 14,12 , sedangkan nilai rata-rata post test sebesar 73,66 dengan simpangan baku 13,64. Oleh karena itu, pada kelas eksperimen kemampuan menulis matematis siswa pada post test lebih tinggi dibandingkan kemampuan menulis matematis siswa pada pre test. Pada kelas kontrol atau kelas yang diajar dengan konvensional nilai rata-rata pre test sebesar 49,45dengan simpangan baku 14,34, sedangkan nilai rata-rata post test sebesar 63,22 dengan simpangan baku ,16. Oleh karena itu, pada kelas kontrol kemampuan menulisi matematis siswa pada post test lebih tinggi dibandingkan kemampuan menulis matematis siswa pada pre test.

Data hasil dari pemberian angket, sebelum dianalisis deskriptif, data tersebut dikonversi dengan metode MSI yaitu mengubah data ordinal ke data interval. Adapun hasil analisis deskriptif dari self efficacy siswa serta pembagian kelompok berdasarkan kategori disajikan pada tabel berikut :

Tabel 2 Deskripsi Angket Self efficacy siswa antar Kelompok Kelas

\begin{tabular}{lcc}
\hline Analisis Deskripsi & Kelas Eksperimen & Kelas Kontrol \\
\hline Rata-rata & 106,319 & 109,661 \\
Simpangan Baku & 6,167 & 8,541 \\
\hline
\end{tabular}

Berdasarkan tabel 2 diperoleh bahwa kelas eksperimen memiliki rata-rata 106,39 dan simpangan baku adalah 6,167.

Sedangkan untuk kelas kontrol memiliki rata-rata 109,661 dan simpangan baku8,541.

Tabel 3 Angket Self efficacy Berdasarkan Indikatornya

\begin{tabular}{ccccccccc}
\hline & \multicolumn{4}{c}{ Eksperimen } & \multicolumn{8}{c}{ Kontrol } \\
Deskriptif & \multicolumn{1}{c}{ IndikatorSelf Efficacy } \\
& $\mathbf{1}$ & $\mathbf{2}$ & $\mathbf{3}$ & $\mathbf{4}$ & $\mathbf{1}$ & $\mathbf{2}$ & $\mathbf{3}$ & $\mathbf{4}$ \\
\hline Rata-rata & 2,66 & 2,06 & 2,61 & 2,7 & 2,61 & 2,69 & 2,55 & 2,80 \\
Simpangan Baku & 0,83 & 0,86 & 0,95 & 0,89 & 0,76 & 0,86 & 0,9 & 0,91 \\
\hline
\end{tabular}

Berdasarkan Tabel 3 diperoleh bahwa pada kelas eksperimen, dengan pengalaman langsung nilai rata-rata 2,66 indikatorself efficacy yang pertama yaitu dan simpangan bakunya 0,83. Pada indikator self efficacy kedua yaitu 
pengalaman dari orang lain nilai rata-rata 2,06 dan simpangan baku 0,86. Pada indikator self efficacy ketiga yaitu aspek sosial nilai rata-rata 2,61 dan simpangan bakunya 0,95 . Sedangkan pada indikator keempat yaitu aspek psikologis nilai ratarata 2,7 dan simpangan bakunya 0,89. Pada kelas Kontrol, dengan indikator Self efficacy yang pertama diperoleh rata-rata
2,61 dan simpangan baku 0,76. Pada indikator Self efficacy yang kedua dengan nilai rata-rata 2,69 dan simpangan baku 0,86. Pada indikator Self efficacy yang ketiga dengan nilai rata-rata 2,55 dan simpangan baku 0,9. Sedangkan pada indikator Self efficacy yang keempat dengan nilai rata-rata 2,80 dan simpangan baku 0,91 .

\section{Tabel 4 Uji Perbedaan Rata-Rata Data N-Gain Kemampuan Menulis Matematis Siswa Kelas Eksperimen dan Kontrol}

\begin{tabular}{|c|c|c|c|c|c|c|c|c|}
\hline & & & \multicolumn{2}{|c|}{$\begin{array}{c}\text { Levene's Test } \\
\text { for quality of } \\
\text { Variances }\end{array}$} & \multicolumn{4}{|c|}{ T_test Equality of Means } \\
\hline & & & $\mathbf{F}$ & Sig. & $\mathbf{t}$ & df & $\begin{array}{l}\text { Sig. }(2- \\
\text { tailed) }\end{array}$ & $\begin{array}{c}\text { Mean } \\
\text { difference } \\
\mathbf{S} \\
\end{array}$ \\
\hline \multirow{2}{*}{$\begin{array}{c}\text { N- } \\
\text { Gain_Eks } \\
\text { _Kontrol }\end{array}$} & $\begin{array}{l}\text { Equal } \\
\text { Assumed }\end{array}$ & Varian & 0,309 & 0,581 & 3,236 & 46 & 0,002 & 0,193 \\
\hline & \multicolumn{2}{|c|}{$\begin{array}{l}\text { Equal varian not } \\
\text { assumed }\end{array}$} & & & 3,22 & 45,3 & 0,002 & 0,193 \\
\hline
\end{tabular}

Berdasarkan hasil analisis pada Tabel 4tersebut, terlihat juga bahwa nilai $\mathrm{t}$ sebesar 3,236dan Sig. (2-tailed) adalah 0,002 . Nilai signifikansi ini lebih kecil dari taraf signifikansi 0,05 yang ditetapkan, sehingga hipotesis nol ditolak. Artinya Secara signifikan rata-rata peningkatan kemampuan menulis matematis siswa yang diajar dengan pembelajaran TTW lebih tinggi dibandingkan dengan kemampuan menulis matematis siswa dengan pembelajaran konvensional. Hasil ini memberikan kesimpulan bahwa ada perbedaan yang signifikan peningkatan kemampuan menulis matematis antara siswa yang diajar menggunakan pembelajaran TTW dibandingkan siswa yang diajar dengan pembelajaran konvensional. Dengan memperhatikan nilai rata-rata $\mathrm{N}$-Gain kedua kelompok pendekatan pembelajaran (TTW dan konvensional), yaitu 0,47 dan 0,28.

Untuk menguji adanya perbedaan peningkatan kemampuan menulis matematis siswa ditinjau dari Self efficacy siswa secara menyeluruh pada kelas eksperimen dan kelas control digunakan analisis uji-F (two way Anova) degan desain Rancangan Acak Kelompok (RAK) dengan taraf signifikansi 0,05. Kriteria pengujian yakni jika nilai sig> $\alpha=0.05$ maka $\mathrm{H}_{0}$ diterima. Artinya semua perlakuan tidak berpengaruh terhadap respon yang diamati. Hasil uji tersebut dsajikan pada tabel berikut : 
Tabel 5. Uji Perbedaan Rata-Rata Data N_Gain Kemampuan Menulis Matematis Siswa Kelas Eksperimen Dan Kelas Kontrol Ditinjau Dari SE

\begin{tabular}{|c|c|c|c|c|c|}
\hline \multicolumn{6}{|c|}{$\begin{array}{l}\text { Tests of Betw een-Subjects Effects } \\
\text { Dependent Variable: NGAIN }\end{array}$} \\
\hline Source & $\begin{array}{l}\text { Type III Sum } \\
\text { of Squares }\end{array}$ & $\mathrm{df}$ & Mean Square & $\mathrm{F}$ & Sig. \\
\hline Corrected Model & $1.375^{\mathrm{a}}$ & 3 & .458 & 19.248 & .000 \\
\hline Intercept & 6.341 & 1 & 6.341 & 266.219 & .000 \\
\hline KELAS & .397 & 1 & .397 & 16.661 & .000 \\
\hline SELF_EFFICIACY & .926 & 2 & .463 & 19.439 & .000 \\
\hline Error & 1.048 & 44 & .024 & & \\
\hline Total & 9.575 & 48 & & & \\
\hline Corrected Total & 2.424 & 47 & & & \\
\hline
\end{tabular}

Berdasarkan data pada tabel 5 pada baris kelas diperoleh nilai $\mathrm{F}$ hitung 16,661 dengan nilai sig $=0,000$. Karena nilai sign $<\alpha=0.05 \quad$ maka $\quad \mathrm{H}_{0}$ ditolak.Artinya, terdapat perbedaan yang signifikan signifikan rata-rata peningkatan kemampuan menulis matematis siswa kelas eksperimen dan kelas kontrol ditinjau dari Self Efficacy.

\section{PEMBAHASAN}

Hasil analisis data baik dari analisis deskriptif maupun analisis inferensial menunjukkan bahwa terdapat pengaruh pembelajaran TTW dan pembelajaran konvensional terhadap peningkatan kemampuan menulis matematis siswa. Setelah membandingkan peningkatan kemampuan menulisi matematis siswa kedua kelas melalui uji statistik inferensial, diperoleh hasil bahwa terdapat perbedaan pengaruh yang signifikan antara pembelajaran TTW dan pembelajaran konvensional terhadap peningkatan kemampuan menulis matematis siswa baik ditinjau dari keseluruhan siswa maupun ditinjau dari self-efficacy siswa. Hal ini terlihat pada nilai rata-rata $\mathrm{N}$-Gain kedua kelompok yang menyimpulkan bahwa nilai rata-rata $\mathrm{N}$-Gain kemampuan menulis matematis kelompok siswa yang pembelajarannya menggunakan pembelajaran TTW relatif sama dibandingkan nilai rata-rata N-Gain
Berdasarkan data pada baris SELF EFFICACY diperoleh nilai $\mathrm{F}$ hitung= 19,439 dengan nilai sig=0,000. Karena nilai sign $<\alpha=0.05$ maka $\mathrm{H}_{0}$ ditolak. Artinya terdapat pengaruh yang signifikan Self efficacy terhadap kemampuan menulis matematis.

kelompok siswa yang pembelajarannya menggunakan pembelajaran konvensional.

Dari kesimpulan yang dikemukakan di atas, dapat dikatakan bahwa faktor pendekatan pembelajaran berpengaruh signifikan terhadap peningkatan kemampuan menulis matematis siswa. Kedua pembelajaran dalam penelitian ini memiliki pengaruh yang berbeda terhadap peningkatan kemampuan menulis matematis siswa. Meskipun kedua prinsip pelaksanaan pembelajaran berbeda.

Penyebab adanya perbedaan pengaruh kedua pembelajaran terhadap peningkatan kemampuan menulis matematis kedua kelas tersebut adalah karena siswa senang dan aktif dalam proses pembelajaran dengan menggunakan pembelajaran TTW dibandingkan pembelajaran konvensional. Siswa sangat antusias dengan hal baru yang dilakukan oleh peneliti.Artinya, kedua model pembelajaran baik 
pembelajaran TTW dan pembelajaran konvensional dapat meningkatkan kemampuan menulis matematis siswa. Pembelajaran TTW dan pembelajaran konvensional mempunyai keunggulan masing-masing dalam proses pembelajaran di kelas. Olehnya itu, pada saat peneliti membandingkan dua pembelajaran tersebut ada perbedaan pengaruh yang signifikan terhadap peningkatan kemampuan menulis matematis siswa baik secara keseluruhan maupun ditinjau dari self efficacy tinggi, sedang, dan rendah.

Secara umum, penelitian ini menyimpulkan bahwa self efficacy siswa mempunyai pengaruh yang signifikan terhadap peningkatan kemampuan menulis matematis siswa baik pada kelas yang diajar dengan pembelajaran TTW maupun kelas yang diajar dengan pembelajaran konvensional. Begitu pula pada perbedaan self efficacy tinggi, self efficacy sedang dan self efficacy rendah terdapat pengaruh yang signifikan terhadap peningkatan kemampuan menulis matematis siswa.

Penelitian ini mengemukakan bahwa pada kelas yang diajar dengan pembelajaran TTW sebagian besar siswa yang memiliki self efficacy tinggi mempunyai peningkatan kemampuan menulis matematis tinggi. Pada siswa yang mempunyai self efficacy sedang sebagian besar siswa mempunyai peningkatan kemampuan menulis matematis sedang meskipun terdapat siswa yang memiliki peningkatan kemampuan menulis tinggi.Pada kelas

\section{KESIMPULAN DAN SARAN}

Berdasarkan hasil penelitian dan pembahasan, maka kesimpulan dalam penelitian ini adalah sebagai berikut: 1) Rata-rata peningkatan kemampuan menulis matematis siswa yang diajar dengan model pembelajaran TTW adalah 0,47 (sedang) dan siswa yang diajar dengan model pembelajaran konvensional yang diajar dengan pembelajaran konvensional sebagian besar siswa yang memiliki self efficacy sedang mempunyai peningkatan kemampuan menulis matematis rendah. Secara umum, siswa yang diajar dengan pembelajaran TTW dan pembelajaran konvensional mempunyai peningkatan kemampuan menulis matematis siswa pada kategori sedang baik siswa yang mempunyai self efficacy tinggi dan sedang .Sedangkan siswa yang mempunyai self efficacy rendah mempunyai peningkatan kemampuan menulis matematis siswa pada kategori rendah.

Pada dasarnya model pembelajaran think talk write (TTW) adalah untuk menumbuh kembangkan kemampuan pemahaman dan komunikasi siswa. Model pembelajaran think talk write dikembangkan oleh Huinker dan Laughlin (Yamin dan Ansari, 2008:84) yang dibangun melalui berpikir, berbicara dan menulis. Prasetyo menyatakan bahwa kelebihan model pembelajaran Think Talk Write adalah sebagai berikut :1) memberi kesempatan siswa berinteraksi dan berkolaborasi membicarakan tentang penyelidikannya atau catatan-catatan kecil mereka dengan anggota kelompoknya.2) siswa terlibat langsung dalam belajar sehingga termotivasi untuk belajar; serta 3) model ini berpusat pada siswa, misalkan memberi kesempatan pada siswa dan guru berperan sebagai mediator lingkungan belajar. Guru menjadi monitoring dan menilai partisipasi siswa terutama dalam pembelajaran.

0,28 (rendah); 2) Rata-rata peningkatan kemampuan menulis matematis siswa yang memiliki self efficacy tinggi adalah 0,592 (sedang), siswa yang memiliki self efficacy sedang adalah 0,392(sedang) dan siswa yang memiliki self efficacy rendah adalah 0,185 (rendah); 3) Secara signifikan rata-rata peningkatan 
kemampuan menulis matematis siswa yang diajar dengan model pembelajaran TTW lebih tinggi dibandngkan dengan rata-rata peningkatan kemampuan menulis matematis siswa yang diajar dengan model pembelajaran konvensional; 4) Terdapat perbedaan pengaruh yang signifikan ratarata peningkatan kemampuan menulis matematis siswayang diajar dengan model pembelajaran TTW dan siswa yang diajar dengan model pembelajaran konvensional ditinjau dari self efficacy;

Berdasarkan kesimpulan yang telah dipaparkan, maka peneliti menyarankan beberapa hal berikut: 1) Model pembelajaran TTW hendaknya dapat digunakan sebagai salah satu alternatif

\section{DAFTAR PUSTAKA}

Bandura, A. 1997. Self-efficacy: The exercise of control. New York: W.H. Freeman and Company.

Effendy, O. 2000. Ilmu Teori dan Filsafat Komunikasi. $\quad$ Bandung: PT. Rosdakarya.

Huinker, D \& Laughlin, C. 1996. Talk You Way into Writing. In. P. C. Elliot and M.J. Kenney (Eds). Years Book 1996. Communication in Mathematics $\mathrm{K}-12$ and Beyond. USA:NCTM.

Junaedi, I. 2005. Penerapan dan Pengembangan Strategi Pembelajaran Seni Budaya dan Keterampilan Madrasah Ibtidaiyah Ruang Lingkup Seni Rupa Murni. Jakarta: Departemen Agama RI Badan Litbang dan Diklat Pusdiklat Tenaga Teknis Keagamaan.

National Council of Teachers of Mathematics (NCTM). 1989. Curriculum and Evaluation Standards for School Mathematics. Drive, Reston, VA: The NCTM.

Sugiyono. 2011. Metode Penelitian Pendidikan Pendekatan Kuantitatif, model pembelajaran bagi guru untuk meningkatkan aktivitas belajar dan mengoptimalkan kemampuanberpikir kritis matematis siswa; 2) Dalam penggunakan model pembelajaran TTW, guru perlu memperhatikan waktu pembelajaran dan lebih membimbing siswa yang memiliki Self efficacy rendah; 3) Peneliti selanjutnya, hendaknya dapat menggali lebih jauh tentang kemampuan menulis matematis siswa dengan menggunakan masalah-masalah atau topik menarik yang menuntut kemampuan tingkat tinggi, sehingga siswa mampu menyelesaikan masalah, baik dalam pembelajaran matematika maupun dalam kehidupannya sehari-hari.

Kualitatif dan $R$ \& $D$. Bandung: Alfabeta.

Van de Walle.J., A. 2008. Matematika Sekolah Dasar dan Menengah : Pengembangan pengajaran jilid 1 . Jakarta : Erlangga. 